\title{
ユーカリの特性とパルプ用造林
}

日本製紙連合会 副理事長 森 本 泰 次

\section{The Character of Eucalypts and its Afforestation for Pulpwood}

Taiji Morimoto

Vice-President, Japan Paper Association

\section{1. ユーカリという名の植物}

植物の名は国により，また同し国でも地方によって まちまちである。そのうえ，用途や生態などによって， 別の名をつけられているものも少なくない。チップと して輸入されているタクラスファは，我か国の木材業 界ではもっぱら米マッと呼んでおり，同様にウエス ターンへムロックは米ッガと呼んでいる。

また，欧米では，樹木の幹や枝に傷をつけた場合に 乳状液（樹脂）を出す木は，樹種に関係なく gum tree とも呼ばれている。後述するように，ユーカリの仲間 にこの性質を持つものが多いため，今でもオーストラ リアではユーカリのことを gum tree と呼んでいる。

このように植物は様々の名で呼ばれ，しばしば混同 を生しるが, この点, 我が国では全国統一名(標集名) としての“和名”が決められているので便利である。 世界でも珍しいケースといってよい。ただし，此較的 新しい外来種の名はまちまちで，ユーカリもそのたぐ いである。

我か国のある植物図鑑には、ユーカリジュ(ユーカ リノキ) という名の樹木が揭裁されている。これはた またま, 明治期頃から洋行記念などとして持ち帰られ たユーカリの仲間のなかで, 最も多かったサザン・ブ ルー・カム (タスマニア・フルー・ガムともいわれる) を、ユーカリの代表としてこのように名づけたものの ようであり，混同を招きやすい。

ユーカリの仲間は 600 種ほどあるとされ，ごく一部 のものを除いてオーストラリアが原産となっている。

これらの標本が Captain Cookの一行によって英国に 持ち帰られたか，何れも開く前の花（花弁とガクは無 く、雌ずいと, 美しい白〜ピンク色の花系を持つ雄ず いだけ）が、ふたによってしっかり保護されていると いう特幑を持っていたため,この仲間をまとめて $1 つ$ の属とし，その属名としてつけられたのが Eucalyptus なのである。ギリシャ語で“eu”は“well”, “kaluptos” は coveredの意とされ，後述する植物命名規約によっ て、このようにつけられたものである。

それまで,これらの植物には gum tree という呼び 名しかなかったため，この植物分類学上の用語がその まま一般化したものである。なお，オーストラリアで はユーカリの一般名として eucalypt（複数は eucalypts）を用いることが提唱され，同国はもとより 英語圈の多くでこれが用いられるようになっている。

このようにユーカリという語は, 特定の種 (species) を指すものではなく，たとえば，我が国のアカマッ， クロマッ，ゴョウマッやハイマッなどを包括する，い わゆるマツの仲間の植物分類学上の属名 Pinus（パイ ナス) と同次元のものであって，一般名の pine (マッ) に相当している。オーストラリアが提唱する eucalypt は,この pine に当たるものなのである。

\section{2. ユーカリの植物分類学上の位罾}

植物の分類方法は，かつては主に形態の差によって いたが、科学の進歩にともなって，最近では連伝学的 な近緑関係，たとえば交配の可能性の程度とか，隔離 分布の状況なども加味されるようになってきた。ただ し，それらの基準は研究者によって必ずしも一様では ない。

植物には, 種子をつけない菌類, 藻類, 蘚苔類やシ タ類があり、これらに対して，種子をつける植物は一 括して種子植物とされている。かつて顕花植物，時に は高等植物といわれてきたものである。

この種子植物には, 雌花の胚珠(動物の卵子に相当) が簬出していて，花粉を直接受けて受精するソテッ， イチョウやマッ類（広くマッ，モミ，トウヒ，スギ, ヒノキなど)，イチイ類(イチイ，カヤ，マキキ,ナギな どで、マッ類と合わせて球果植物とされることがある) のような裸子植物と，一方，雌しべを持ち，その基部 
（子房）に肧珠が包み込まれて，雌しべを経て受精後、 その基部 (子房) が肥大して果実または種子の容器（さ やなど）となる被子植物がある。

前者の裸子植物の多くは形成層（木部と皮部との間 にある細胞分裂層) を持ち, 成長を続けて, いわゆる 樹木となるが,この類の大部分のものが, 幅が狭くて 針状に近い葉を持っているため,ソテッやイチョウな ども含めて，樹木型となる裸子植物二針葉樹とされる ことがある。

後者の被子植物はイネ, ムキ, タケ, シュロ, ヤシ などのように, 子葉 (種子が発芽する際に, 最初に出 てくる葉) が 1 枚の単子葉植物と, 子葉が 2 枚 (二葉) の双子葉植物に分けられる。

単子葉植物には形成居が発達しないため, シュロの ように永年性の植物であっても年輖などは形成されず， 太さもおのずと限られてくる。

一方, 双子葉植物には，おびただしい数の単年性あ るいは宿根性の草木類があるほかに, 形成層を持ち, 成長を続けて樹木となるものがある。一般に広葉樹と いわれているものがこれに属している。

後者の双子葉植物は, さらに, 各花弁のもとがッッ ジのうに1つに合わさった合弁花類と, サクラのよ うに各花弁がバラバラになって散る踓弁花類に大別さ れ, それぞれに, 幾つかの形態的特徽点や発生系統的 な観点などから，科，さらには属へと区分されていく。 ユーカリは種子植物で, 被子植物のなかの双子葉植 物, 離弁花類に属し、その1科であるフトモモ科 (果 樹のフェイショョアの属など約 90 属がある) の 1 属, Eucalyptusの植物ということになるわけで，そのほと んどが葉面にクチクラ層 (角皮) を持つ常緑性の広葉 樹である。

\section{3. 針葉樹と広葉樹の区分}

本題からはいささかそれるが、ユーカリか国際的に も広葉樹パルプの主原料となってきているため,ここ で, 粉らわしい針葉樹と広葉樹の区分について, 私見 も含めて触れておきたい。

もともと針葉樹, 広葉樹という呼び方は, 葉の形に よる常識的なものであって, 植物学的な区分ではない。 したがって，その何れにも属さないものがあってよい のたが, しばしばすへての樹木を，何れか一方に仕分 けようとするため湿乱が生している。

国によって自生する樹木の種類は大きく異なるか， 外国でも，我が国の针葉澍に相当する言葉として，英 語では conifer, coniferous tree や needle leaved tree, soft wood とと,ドイッ語では nadel baum, nadel holz
などがあり，広葉樹に相当するものとしては，英語で は broad leaved tree, hard wood などドイツ語では laub baum, laub holz などがある。

国際化が進む時代であり，また，もともと針葉樹， 広葉樹という言葉自体が, これらの外国語に由来して いるものであるため, 外国語をべースに, 前項で述へ た植物分類方法を組み合わせてみると, 種々の面で好 都合な仕分けが可能となってくる。

すなわち，裸子植物のうち，マツ類，イチイ類を合 わせた球果植物だけを針葉樹とすれば，欧米に広く分 布する conifer (球果植物, 針葉樹) とほほ一致し, 木 材組織の点でも仮導管が主体の soft wood と整合する。 同様に広葉樹を被子植物の双子葉類樹木と限定すれ ば, 葉形はもとより，木材組織的にも，導管と木㳦維 を持つ hard wood のクループと整合する。

ただし、ナキやナンョウスギ科のアカチスのように 葉幅がかなり広いものが針葉樹に，また，葉が極めて 小さく，一見針葉樹と思われるモクマオウなどが広葉 樹に人ってくるのは，どのような区分方法によっても 避け難い。

いうまでもなく，仮導管がほとんどの針葉樹（球果 植物, conifer) と, 木载維が $5 \sim 6$ 割, 導管が 2 割前後 の広葉樹 (双子葉類の樹木) とでは, パルプの性質が 異なるため，木材パルプは針葉樹パルプ $(\mathrm{NP})$ と広葉 樹パルプ (LP) に分けられている。

ここでの NP, LP の略称は, 日本工業規格(JIS)の 紙・パルプ用語で定めている「針葉樹パルプの略称は $\mathrm{NP}$ (N はドイツ語の Nadelholz の佫), 広葉樹パルプ の略称は LP (L はドイッ語の Laubholz の略)」による ものである。なお,この紙・パルプ用語では, 対応英 語 (参考) として, 前者に softwood pulp, 後者に hardwood pulp が付記されている。

しかし，諸外国ではJISのような用例はほとんど聞 かない。木材パルプの製造がドイッに始まったためか とも考えられるが，当時はすべて針葉樹パルプである。 どうやら当時, パルプ製造学を含めていたドイツ林学 が，明治初期に丸こと我が国に輸入されたことに由来 するものと思われる。林野庁でも，今もって針・広の 区分にN・Lを用いることが少なくないようである。

外国の広葉樹パルプでは Eucalypt Pulpなど, 樹種 名を冠するのが一般的であるが，我が国ではミックス 広葉樹が多く用いられるなどの特翼点はあるものの， 国際化時代を迎之，これらパルプの名称に一工夫が あってょいように思われる。 


\section{4. ユーカリの種 (spesies)}

発見された植物で，それが他とは明らかに異なると 鑑定されれば，動物と同様に国際命名規約によって名 前が付けられる。これが学名といわれているもので, イタリックで，最初に属名を書き，次にその植物の特 徵点を表わす形容詞とか特産地名, 由来などを短く表 現した語を記し，最後に命名者名（鑑定者や学会報告 者の名が多い)をつけることとなっている。

属名の頭文字は大文字, その次の形容詞的語はすへ て小文字とされ、ラテン語またはラテン語化した語か, キリシャ語で記载することになっている。たとえば, 先に述へたューカリジュ(ユーカリノキ)の学名は Eucalyptus globulus LABILL.である。なお，一般には 属名は頭文字だけとし，命名者名を路して，E， globulus とすることが多い。

この E. globulus (クロブラス) は E. camaldulensis (カマルドゥレンシス) とともに，世界で最も広範に， かつ多く造林されている種で，我か国の製紙業界の造 林プロジェクトでも，チリ，オーストラリアなどでは 前者が,タイ、ベトナムなどでは後者か用いられてい る。なお、ブラジルのプロジェクトでは E. grandis が 主で，一部に E. saligna が用いられている。

しかし，先に述へたように植物の分類基準は，研究 者によって多少異なるため，たとえば我が国のように， 葉の大小，広狭や，葉面の毛の有無といった小さな相 違点でも，それが速伝的に継承され，㻴境などによっ て変化しない固定的な特性であることが確認されれば， 独立の種 (spesies) として扱うことがあれば, 相違の 程度により，亜種（subspesies：略号 subsp.）とした $\eta$, 変異種 (variety：略号 var.) とし, 母体名の後に 連記することもある。また, 時には系統 (品種) 程度 の报いとする研究者もあり，これらは学派による面か 少なくないようである。

たとえは，前記の E. globulus は，それまで，これと は別種とされてきたE. maidenii などと合わせて，そ れらを統合する種の一亜種とし, E. globulus subsp. globulus とされることがある。

今までにユーカリ属の種として命名されたものは, 672 種との記述がある一方, 約 500 種とするものがあ るなど様々で，流動的要素を多分に含んでいる。上記 のような分類基準の差によることはもとより，調查が まだ充分に行き渡っていないであろうことや，環境に よると思われる变翼が大きいこと，さらにはユーカリ の場合, 天然での種間交雑種とみられるものが多いこ となどがあるからである。
たとえば，E. camaldulensis はオーストラリアでは 産地によって Petford 系など 8 つ地方系（品種）に 分けられ，形態はもとより，造林適地や成育などにも 差か認められている。なかには材質にも差があるなど で，他種との交雑か疑われているものもある。ちなみ に，筆者が当初からかかわってきたタイのユーカリプ ロジェクトでは, 農民が造林している本種の産地, 系 統が不明確で，個体間の変暴差が余りにも大きく，そ の選抜が技術面での最大課題となっている。

また, ブラジルでE. albaに似ているために通称フ ラジルアルバといわれ，広く造林されてきたものは， もともとはインドネシア・チモール島などが原産の $E$. urophyllaであるが, 本種は交雑しやすいため, 導入さ れたフラシシルの Rio Claro 樹木園で，本種を母方（種 子をつける方) として，近くに植えられていた E. ter eticornis か E. saligna，あるいはE. alba を父方（花 粉）として交雑した種子が，拡散したことによると見 られている (FAO 報告)。このような例は，我が国の マッやカンバの類などでもままみられるが, ユーカリ では多いようである。

\section{5. ユーカリの類型区分}

ユーカリの種は多く，そのほとんどがオーストラリ アの原産で，マメ科，ネムノキ要科のアカシア属（約 1,000 種とも 550 種程度ともいわれる)とともに, オー ストラリアの植生を他大陸と際立って翼なったものと している。動物の有袋類の生息などと合わせて，オ一 ストラリア生物区系とされ，他大陸の生物系とは異 なった报いとされている。

このユーカリを生態，形態や利用面などの特啠をも とに幾つかに類型化してみると次のようになる。

\section{1）天然分布地城による区分}

（i）オーストラリア以外の地域にも分布するもの E. alba(パプアニューギニア，インドネシア・チモー ル島など)，E. tereticormis (パプアニューギニア)，E papuana (パプアニューギニア) などの 5 種がある。

(ii）オーストラリアには分布しないもの

E. deglupta (パプアニューキニア，フィリピン・ミ ンタナオ島，インドネシア・モルッカ諸島)，E. uro. phylla（インドネシアのチモール島，フローレス島な ど), E. schlechterii (パプアニューキニア) の 3 種が 確認されている。

このようにオーストラリアを外れてユーカリが分布 する地域は，生物学的にオーストラリア生物区系と見 なされ、これと東洋生物区系との境界線をなすバリ島 の東側からミンタナオ島の西側を結ふ線が, 生物学で 
有名な Wallace 線といわれているものである。

なお，E. deglupta（現地名カメレレ）は成長が極め て早く，本州製紙パプアニューギニアプロジェクトの 造林樹種とされてきたが, 幼䯍時から材の心腐れ (heart rot)の発生が多いことと, 舥乾比重が 0.4 程度 以下と低いこと，さらには萌牙更新ができないことな どから，最近では Acasia mangium に転換されつつあ る。

また,E. urophylla はチモール島では標高 $3,000 \mathrm{~m}$ 近くまで分布し，なかには幹が多数に分忮するものな ど，様々な系統（生態型）のものがあるとされるが, 一般に成長が早く，採種地（標高など）によっては樹 形もよく，極めて良好な造林成績を示すものがあるた め, ブラジルでは高収穫品種の交配育種用にも用いら れている。また, 中国広東省では 1990 年頃から本種の 本格造林が始められていた。

\section{2）生態的特幑による区分}

(i) マリー型ユーカリ

オーストラリアの南西部と, 一部東南部の乾嬠地帯 (年降雨量 300 500 mm) の草原（サバンナ）に分布 し, 現地で Mallee といわれている低木性の種群で, 高 さ数 $\mathrm{m}$ 以内の株立状 (かん木状) となっている。土中 に埋まった根元部に lignotuber (root ball) といわれ るコブ根組織を持ち, 水分や養分を貯え, 干ばつ, 野 火や動物などの害を受けると旺盛に萠芽し再生する。 このタイプのものは約 100 種あるとされている。

このコブ根組馀は, 程度に差はあるもの大部分の ユーカリは持っているといわれるが, 造林にも用いら れるE. grandis や E. pilularis などには見当らないと もいわれている。

\section{(ii) 草原樹林型ユーカリ}

オーストラリアの内陸乾嬠地の北部から，東南部の 森林帯の内側にかけての半乾嬠地域 (年降雨量 400 ～700 mm）に分布する種群である。樹高は 20 25 m 程度で, 広い草原に ha 当たり 200 本程度ないしはそ れ以下に㻋生, または点生するタイプで, サバンナ林 の典型といってよい。

樹幹は一般に太く，大きな樹冠を拡げているが，こ れらのなかには次項の森林型にも出現し，かなりの樹 高に達しているものがあるとされる。

(iii) 森林型ユーカリ

年降雨量が $800 \mathrm{~mm}$ 程度以上のオーストラリア南東 部沿岸地域と, 南西部沿岸地域の一部やタスマニア島 などでは, 各種の高木性ユーカリが優占する森林が形 成されている。最大の美林は年降雨量が $1,000 \mathrm{~mm}$ 以 上のヒクトリア州のキブスランド地方, 西オーストラ
リアのスワンランド地方やタスマニア島などで見られ， 平均樹高が $50 \sim 60 \mathrm{~m}$ にも達しているという。特に夕 スマニア島では, 広葉樹では世界最大といわれる樹高 $99 \mathrm{~m} の$ E. regnans (Giant gum) が確認されている。

我が国にチップ輸出が行われている地域の主要な天 然林ユーカリの樹種は，南東部とタスマニア島では $E$. obliqua, E. delegatensis, E. Saligna, E. regnans, E. pilularis なと，南西部では $E$. diversicolorなどであ る。

（iv） 積雪地型ユーカリ

オーストラリア南東部山地の高海抜地で, 年間降霜 日が 150 日以上, 積雪期間が数力月にわたる地域でも， ユーカリが 10 種ほど天然分布しており，一般に Snow gum といわれている。中一低木で写真で見るところで は，我が国の高山森林限界近くに成育するタケカンバ と同じような生態形をしている。

\section{3）樹皮や材復なとによる区分}

ユーカリは，成長にともなって樹皮が剝落（樹幹基 部を除く)するタイプと，剥落しないタイプに大別さ れるほか，材質などによって幾つかのタイプに分けら れている。

（i）樹皮が制落型のユーカリ

このタイプのユーカリは，先に述へた傷口から乳状 液を出す gum treeのことでもある。オーストラリア で,ユーカリの名にこの gum という語がつけられてい る種は，全体の約 4 割を占めるといわれ，一般に成長 の早い高木性のものが多いことから，ユーカリの代名 詞となっているものである。なお，この gum はゴムと して利用されるパラゴムノキなどの水溶性樹脂とは異 なる不水溶性の樹脂である。

樹皮が剝落する時の形には，細長く剝げてリボン状 にぶら下がるもの（E. globulusなど）や，広く大きい 板状に剥げるもの (E. camaldulensis, E. saligna な ど)，小薄片または鳞状に永げるもの(E. citriodora な ど）など様々なものがある。

また，樹皮が剝げた後に現れる新皮の色は一般に明 るく,その色によって Blue gum, Gray gum, Red gum, Pink gumなとに分けられている。たとえば，E． globulusのオーストラリア名は, 先に述へたように Southern blue gum または Tasmanian blue gum で, 同国の植物図鑑などでは，もっばらこの名称が用いら れている。

樹皮の剝落後に, 鮮やかなブルーやピンクの新皮が 現れるものなどは，成長の早さ，独得の樹形や葉形な どとともに，導入された地域の住民に異様な感じを与 えたようで，東南アジアなどでは磨物とさえ言われて 
いる地域もある。

（ii） 樹皮が固着型のユ一カリ

固着型の樹皮も，幼䑪時は平滑であるが，成熟にと もなってコルク層が厚く発達したり, 縦に深い溝がで きるなど,様々な形を示すようになる。その様子によっ て, Iron bark とか Stringy barkなどのタイプに分け られている。前者に属するものにはE. paniculata (Gray iron bark) などのように材質が硬く, 耐久性に 富むものが多く, 器具, 甲板, 車両, 枕木などに用い られている。

(iii）その他のタイプのユーカリ

上記の（i ）（ii）の区分にかかわりなく，材犋か 欧州ツゲ (box) に似ているE. albensなどを Box 類, 欧州トネリコ (ash) に似ているE. delegatensisなどを Ash類, マホガニーに似ているE. robustaなどを Mahogany 類などとし, また，葉に芳香性油を持つも のを Peppermint 類, gumが赤色 (kino) のものを Blood wood 類などとし，オーストラリア名で White box (E. albens のこと) とか, Swamp mahogany ( $E$. robustaのこと) などと呼んでいる。

\section{4）萌芽性による区分}

ユーカリか, 基本的にはコブ根組織 (lignotuber)を 持つグループであることからも明らかなように，萌芽 性は一般に強い。このことが, 降雨量が少なく，しば しば野火に裝われる地域の多いオーストラリアで，今 なおユーカリが優占種となっている理由の一つとされ ている。

しかし，降雨量の多い南東部やタスマニア島の森林 型ユーカリのなかには，E. regnans, E. delegatensis, E. pilularis などのように萌芽性の低いものがある。さ らに,パプアニューギニアなど熱带多雨林带が原産の E. deglupta (カメレレ) のように, 萌芽が全く期待で きないものもある。

萌芽性の高いユーカリでは，たとえば日伯紙パルプ 資源開発䏀のプロジェクトのように，植付後 7 年目ご とに伐採即萌芽更新を行い, 21 年目に第 3 回の伐採を 行って新しい苗木に植替える（切り株は萌芽しないよ うに震土する）という，コスト的に有利な施業法が可 能となるわけである。

幸い，上記の幾つかの種を除き，大部分のユ一カリ は萌芽更新が可能である。萌芽力は一般的に若蛤のも のほど強く，多数発生するため，1～2 本を残して整理 (芽かき) する。伐採当年に $2 \sim 3 \mathrm{~m}$ 程度以上は伸ひる のが普通であるから，林地が裸地化する期間は極めて 短い。中国では萌芽が一定の大きさに達してから地域 住民に整理させ，橏として利用させていた。共存策の
一つといってよい。

\section{6. ユーカリは陽性樹}

植物には太陽の直射光を好む陽性種から，うす暗い 林内にしか生えない陰性種まで種々ある。なかには若 㱓時は耐陰性が強く，成長して他の樹冠から抜き出る ようになると陽性を增すものも少なくない。

我が国のシラカンバ，アカマツ，カラマツなどは陽 性樹（陽樹）の代表的なものであるが，ユーカリはこ れらにも勝る陽樹といってよく，成長の極めて早い種 が多い。

森林が火災，崩壤や伐採などで完全に破溒されれば， 先ず最初に生えてくるのは陽性草本と陽樹である。や が陽樹が成育し，その樹冠が閉鎖するようになると， その下では自身の後継きも含めて陽性種は成育できな くなるから，我か国の場合では，シイ，タブノキ，モ ミ,トドマツなどのように若䑪時に耐陰性の強いもの が徐々に生え育つようになり，やかて陽樹と交替して くる。その等極の姿が植生道移の極相(climax), いわ ゆる原生林とか Old growth といわれているものであ る。

一般に幼時から陽性の強い樹種は，成長が早くて短 命のものが多く，一代限りで終るのが普通であるから， 先駆樹種 (Pioneer plants) ともいわれている。これら は常に陽光の充分な新天地を求めて移動する必要があ ク，たとえばマッの種子に翼があるように，相応の機 能を持つものが多い。

先に述べた世界最大の広葉樹とされるタスマニア島 の E. regnans (Giant gum) でも，樹䑪はせいぜい 200 年程度とみられている。ただ，オーストラリアの場合, 森林を構成する樹種の $95 \%$ 程度がユ一カリ属といわ れておりこれにとって代る高性の他の樹種群が存 在していない。このため, ユーカリ林か寿命に達し, または火災や伐採で破壤されれば，次世代も再びユ一 カリ林となるわけである。

以上のことからも明らかなように，ユーカリ林で皆 伐を避け，択伐（抜き伐り）を行うことは，残存木の 成育にとっては有奻であっても，後継ユーカリの発生， 成育を不十分なものとし，結果的に森林のシリ负を招 くこととなるのである。

したがって，ユーカリ林の伐採，更新では ha 当たり 数本程度の母樹を残して他を皆伐し，さらに，日陰と なる草本類や低木類の抑制と，ユーカリ種子の発芽促 進などのために，伐採跡地に火入れを行う例が多く なっている（全部伐採し，播種する場合もある）。

このような事情が理解されず, ユーカリ林の皆伐や 
火入れ作業が山荒しとして批判されているのは，余り にも非科学的というほかはない。陽樹である我が国の アカマッ，カラマッなどでも類似の方法かとられてい るのである。ただし，作業効率を重視する余り，必要 以上に大面積の皆伐を行うことは，責められても致し 方のないことであろう。

なお,ユーカリには crown shy という特性があると される。樹冠や枝が互いに触れたり重なり合うことが ないように配置された形となることを指しているのだ がまさに陽樹の特性を示すものといってよい。日陰 になる下枝は枯れて次々に落枝し，上部だけに疎開し た樹冠を持つ不安定な樹形となることが多い。

\section{7. ユーカリの造林適性}

ユーカリ属の天然分布区域は，オーストラリア生物 区系に限られてはいるものの, 熱帯から要寒帯（北稦 $10^{\circ}$ から南緯 $43^{\circ}$ ) まで, 海辺から標高 $3,000 \mathrm{~m}$ 付近ま で，さらにはサバンナから多雨林まで，実に広籍な地 域にわたっている。

樹種，産地などの選択が適切であれば，環境保全用 や緑化樹用などでは，寒帯地域を除くほとんどの地域 での植栽が可能であり, 国連食糧農業機構 (FAO) の 調查でもほほ世界中の国に及んでいる。ちなみに，ボ リビアでは標高 $3,400 \mathrm{~m}$ 以上の所で立派な街路樹と なっており,ペルーでは $3,000 \mathrm{~m}$, インドでは $1,000 \mathrm{~m}$ の所に造林して成功している例があるとされている。 また, マリー型のものも, 庭園の刈り込み用などとし て利用されている。

我が国でも記念樹や緑化樹などとして植えられ，か なりの大机育っているものが, 関東地方でも各地で 見られる。まとまった戦前の造林としては，大正初期 に高知県内で行われたユーカリの葉から精油を採取す る目的での 5 ha の造林 (E. globulus が主) や, 昭和 11 〜 12 年に九州大学演習林が行った約 1 ha の林地への 種子直接播き試験などがあり, 戦後では森林资源不足 对策として, 昭和 27 年頃から取り組まれた, 主として 関西の太平洋側地域での，かなりの規模の造林がある。 しかし，記念樹や緑化樹のように平地に植えられた ものの成育が比較的良好であったのに反し，山地斜面 で，量的にまとまった規模で造林されたものは，ほと んどが失敗に終っている。原因は十分に解明されてい ないが, 霜, 低温や風・雪害のほかに, 多分に土壤層 の浅さによるところが大きいと考えられている。

ユーカリの多くはもともと乾地性で, 水分確保のた めに深根性のものが多い。そのため, 原産地では地形 が緩やかで，土壤流亡が少なく，土锖層の厚い地域に
根を染く，広く張って成育しており，山地斜面に分布 しているものは比較的少ない。特に，降雨量が成育期 である夏に少なく，冬に多いオーストラリア南半部の 冬雨型地域に分布するユーカリでは，この傾向が一層 顕著となっている。地形が急で，土壤層が著しく浅い 我が国の山地で，イタリアポプラ（原産地は不明確） がそうであったように，ユーカリ造林の成績が劣る大 きな理由と考えられているのである。地中海地方も典 型的な冬雨型であって，ポプラは河畔などで沖積土層 の梁い地帯に多く造林されている。

このほか，スギやヒノキと同様に畑で育てられた ユーカリの苗木は，根が張り過きて造林の際の活着を 悪くしたことも考えられる。ちなみに，ユーカリの育 苗は最近では国際的にもほとんどポットによっている。 また，下枝が枯れ上がり，樹幹の下部と上部の直径差 が小さく，樹冠の位置が高くなるユーカリの特性は， 伐出作業や丸太の採材率の面では有利であるが, 風・ 雪害には弱い。多雨で草本類やつる類か繁茂する地域 では, 十分な保育作業(尔难で，植栽後 $1 \sim 2$ 年間は年 に2 4 回)も必要となってくる。もっとも，パルプ用 のように 10 年前後で収穫され, ha 当たりの植付け本 数が 1,500 本前後と多い場合には，ユーカリの樹形の 特幑は余り現れてこない。

一方, 数多いユーカリのなかには, 異的といって よいほどの幅広い立地適応性を持つ種がある。たとえ ば，すでに述へたように世界で最も広籍に，かつ多く 造林されているE. globulus と E. camaldulensis につ いてみると,E. globulus は夕スマニア島を主とする一 部地域の, しかも標高 $400 \mathrm{~m}$ 程度以下の低山帯に多く 分布し，まれに $1,000 \mathrm{~m}$ 程度の所まで分布するものか あるとされるが, 現在では世界各地で造林されるよう になっており，先に述へたボリビア，ペルーなどでの 高所植栽例も本種となっている。

また筆者の調查では，E. camaldulensis は夕イでは 毎年の雨季に $2 \sim 3$ 力月間も浸水するような地域(オ一 ストラリアでも同様の地域に分布するものがあるとい う）で，かなり良好な成育を示している一方，年降雨 量が $800 \mathrm{~mm}$ 程度の夕イ東北部平原で, 表土に塩が 真っ白く析出したような地域でも，耕法植栽を行った ものなどでは，まずまずの成育をしている。

さらにユーカリのなかには，E． robusta (Swamp mahogany)などのように, 沼や塩水河口の縁の湿潤地 にまで成育しているものもあるといされる。なお，夕 イ東北部平原での塩の析出は, もともとこの地域が海 底隆起平原であり，戦後の焼畑などによる森林の消隇 で樹木による水分蒸散量が減少し，地下水位が上䄯し 
たためと解されている。

\section{8. 世界のユーカリ造林}

FAOの調査によれば，環境緑化用なども含む世界の ユーカリの造林面積は, 1955 年には 70 万ha であった ものが, 1977 年には 392 万 ha となり,さらに 1990 年 では表 1 のように熱帯地域だけで1,006 万ha，うちア ジア太平洋地域が 520 万 haにも達している（熱帯地 域以外の調查は行われていない)。

この表 1 では国別が明らかでないため，参考までに 1977 年の調查結果でこれを見ると表 2 のとおりであ る。最も多いのはブラシル (105 万ha)で，インド(45 万ha）がれに次き，以下，スペイン，南アフリカ連 邦，ポルトガルなどの順で，合計 92 カ国に及んでい る。

また, 同様に 1977 年の調査結果で, 熱帯地域につい てのユーカリの主要樹種別，国別の人工林面積を見る と, 棇計では世界のユーカリ人工林面積 (392 万ha) の 59\% (231 万ha) を占めている。このうち, 樹種別 で最も多いのはE. saligna（34\%）で，ブラジルを主 にアンゴラ、コートジホアール，モザンビークやへト ナムなど, 次いで E. tereticornis (34\%) がインド, ブ ラジルを主にへトナム，ミャンマー，コンゴなど，E. camaldulensis (10\%) がアンゴラ, エチオピア，マタ ガスカルをはじめ世界の多くの国で造林されており， このほか E. globulus, E. degluptaなどが次いでいる。

一方, 温帯のスペイン, ポルトカル, イタリーや米 国のカリフォルニア州などでは，E. globulus とE. camaldulensis が主流で，世界全体ではこの 2 樹種が 首位と見られている。

これらの造林は，すでに述べたようにユーカリの成 長が早く，立地適応性に幅広いものを持っているため に，㜔畑や放牧，乱開発などで草原化した地域（東南

表 1 熱带地域の主要樹種別人工林面稹（1990 年） (単位：千ha)

\begin{tabular}{|c|c|c|c|c|}
\hline \multirow{2}{*}{ 地 } & \multicolumn{4}{|c|}{ 主要樹種別人工林面積 } \\
\hline & ユーカリ & マツ & チーク & アカシア \\
\hline 中 南 米 & 4,074 & 2,776 & 15 & - \\
\hline アフリカ & 790 & 610 & 145 & 250 \\
\hline アジア太平洋 & 5,200 & 1,250 & 2,020 & 3,150 \\
\hline 計 & 10,064 & 4,636 & 2,180 & 3,400 \\
\hline
\end{tabular}

資料：FAO 森林資源評価 1990 年プロジェクト第 3 次中間報告
表 2 主要国別のユーカリ人工林面積 (1977 年)

\begin{tabular}{|c|c|c|c|}
\hline & 国 & & 積 (ha) \\
\hline ブ & ラ $\quad シ ゙$ & ル & $1,052,000$ \\
\hline イ & ン & F & 450,000 \\
\hline ᄌ & ペ イ & ン & 390,300 \\
\hline 南 & ア ᄀ リ & 力 & 347,500 \\
\hline ポ & ルト カ & ル & 250,000 \\
\hline$\checkmark$ & タがスカ & ル & 180,000 \\
\hline$€$ & 口 \% & $\sqsupset$ & 177,700 \\
\hline U. & $\mathrm{S}$ & A. & 140,000 \\
\hline ウ & $ル ク ゙ ア$ & 1 & 111,100 \\
\hline$P$ & ン ゴ & ラ & 100,600 \\
\hline ペ & ル & - & 92,900 \\
\hline$P$ & ルビンチ & ン & 80,000 \\
\hline 中 & & 国 & 52,000 \\
\hline I & 千 オ & $P$ & 42,300 \\
\hline$千$ & $x=\xi$ & $P$ & 42,000 \\
\hline 1 & 夕リ & - & 38,000 \\
\hline キ & $=\quad-$ & ハ & 36,000 \\
\hline 千 & リ & - & 31,100 \\
\hline そ & の 他 74 力 & 国 & 303,500 \\
\hline & 合 & & $3,917,000$ \\
\hline
\end{tabular}

資料：FAO 報告

アジアなどではチガヤ：インドネシアでいうアランア ランの広大な草原と化している地域が多い）砂漠化 などが進む地域（アフリカのサへルなど）の早期緑化 や, 薪炭材, 建筑用材, 坑木, 枕木などの供給, 雇用 の場の提供（我が国の戦後造林も，この目的を兼ねて 公共事業としてスタートしており，主要造林国といわ れるものに、このケースが多い）などとして, 地形が 粰やかで, 利用度の低い草地などを広く持つ開発途上 地域を中心に，急速に拡大しているものである。

ただ、ユーカリ材の多くは，木理（木目）などの点 で在来種に劣ると評価される向きが強く、今なお一般 用材としての市場性はそしい。その一方で成長が早く， 萌芽性に富み, 病虫害も現状ではアリの食害程度で少 ないため, 低コストで早期収入が得られ, 需要量も多 く,かつ增大傾向にあるパルプ用を主に,一部パーティ クルボードやファイバーボード用などとして造林され るものが増加している。なお，我が国では木質ボード 類の生産量 (1990 年) のうち, 合板が $77 \%$ を占めてい るが, 旧西独では $95 \%$ ，米国でも $42 \%$ が木材チップを 利用するパーティクルなどの非合板ボードとなってき 
ている。

\section{9. パルプ用のユーカリ造林}

パルプ用を主目的とするユ一カリ造林で，歴史的に 古い国としてはスペイン，ポルトガルやブラジルなど があげられよう。パルプ用であるためには, 当然, パ ルプ適性が問われるが，それ以前の問題として，造林 した苗木が，その立地条件に適して確実に成林する樹 種, 系統のものであることが前提となってくる。林業 でいう「適地適木」の大原則がこれであり，したがっ て，パルプ適性は，この条件にかなった樹種について 問われることとなるわけである。用地選択の自由度が 低い土地産業の宿命といってよかろう。

特にパルプ用造林では，広大な用地を長期にわたつ て確保する必要がある。ちなみに，東南アジアや大洋 州諸島でのユーカリ造林木の ha 当たり年平均樹幹材 積成長量 (Mean Annual Increment/ha : MAI/ha) は, 大よそ $20 \mathrm{~m}^{3}$ (10 年生で ha 当たり $\left.200 \mathrm{~m}^{3}\right)$ 前後と 見てよい。これに丸太の採材やチップ化の歩留りを考 虑すれば、チップ生産量としては年平均 $15 \mathrm{~m}^{3} / \mathrm{ha}$ 程 度となろう（タイの農民などは直径 3４ $4 \mathrm{~cm}$ のもま で採材しているが, 非効率である)。

ここで 4 万 t (D.W.T.) 程度のチップ輸送船を用い るとして, 往復 1 力月程度 (北米西海岸程度の距離) の地域で考えてみると, 年間のチップ輸送量は約 40 万 $\mathrm{m}^{3}$ にもなり,これを 1 地域の造林地で供給するとすれ ば，その用地としては 27 千 ha もか必要となってくる わけである。2 地域以上の挂け持ちとか小型船の利用 など, 方法はいろいろ考えられようか, 諸施設の整備 などコスト面から考えても，最低でも10 千 ha 程度の 用地は必要であり，現に製䉻各社の 1 地域当たり最低 造林規模もこの程度となっている。

海外造林事業にとって最大の課題は, この用地の確 保にあるといって過言ではない。昭和 45 年に設立され た社南方造林協会が, 武験造林を行ってきた東南アジ アや大洋州諸島地域で, 事業化に至っているのはパプ アニューギニアの本州製紙プロジェクトたけであって， 最近のプロシェクトのほとんどがチリ，ニュージーラ ンドなどの遠隔地や, 社会主義体制のへトナムなどと なっているのも, また, 夕イのプロジェクトが農民と の契約栽培方式となっているのも，この用地問題によ るところか大きいといってよい。

一般的に開発途上地域では, 慣習共有地 (Customary Land, Native Land) が多く，また，たとえ国有 地とされているところでも, 今なお地域住民の生活と 深くかかわっているところが大部分だからである。ち
なみに，本州製紙のパプアニューギニアのプロジェク 卜は山火事再生林が対象で，政府の総合開発計画の一 環として手掛けられてきたものである。

\section{0. 製紙業界の海外造林プロジェクト}

我が国の製紙業界では, 1950 年代の後半から 1960 年代にわたり，国内で約 15 万 ha の造林を実施すると ともに, 1970 年には主要 7 社(後に 10 社となり, 現在 9 社)で(社南方造林協会を設立し, 東南アジアや大洋州 諸島での試験造林に着手した。

これに次いで, 1971 年には日伯パルプ資源調査俐が 発足したが，同社は1973 年に，製紙会社 17 社と伊藤 忠商事，それに海外経済協力基金 (OECF) か閣議了解 を得て出資参加のナショナルプロシェクトとして, 日 伯紙パルプ資源開発㑣)々と発展している。

また, 1975 年からは国際協力事業団 (JICA) の融資 によって，先に述へた本州製紙パプアニューキニアプ ロシェェトのもととなった試験事業や，三菱製紙によ るニューカレドニアでの試験事業が実施されている。

しかし，このような海外造林への取り組みも，その 後, 発生した二度にわたるオイルショック, 特に第二 次オイルショック時の輸入チップ洒格の高騰や, これ らにともなう古紙利用の拡大などで, 事情は全く一変 している。1973 年に 1,032 万 $\mathrm{t}$ (パルプ材消費量では 3,300 万 $\mathrm{m}^{3}$ ) にまで達した国内パルプ生産量は大きく 減少し，その後，1975～1986 年の 12 年間にわたって 900 万 $\mathrm{t}$ 前後 (パルプ材消費量では 3,000 万 $\mathrm{m}^{3}$ 前後) のままで推移しているのである。

このため, 上記の造林プロジェクトも，すでに本格 事業に着手していた日伯紙パルプ資源と, 本州製紙の プロジェクトを除き，他は試験事業終了とともに事実 上中止の状態に置かれてきた。

このように長い停滞期を経た製紙業界の海外造林事 業も, 1985 年からの円高・ドル安の進行, 石油価格の 安値安定と紙需要の增大なとのほか, 古紙利用率の伸 び止まりや環境問題の台頭などがあって，事情は大き く転じ，再ひ稓極的な取り組みが行われるようになつ てきた。

以下, 本誌の要請もあるので, 以前からのものも含 めて, 各プロジェクトの造林状況（計画）などを中心 に，要点だけを記しておこう。表 3 はその一臨である。

（1）社南方造林協会

1970 年に設立以来, 1976 年までに 4 力国 8 力所で, うち 1 カ所 (ソロモン諸島国) は共同, 他は会員各社 の担当により合計 1,384 ha の試験造林を実施した。試 験樹種の主なものはカリビアマッなどの熱帯産 Pinus 
表 3 製紙会社の海外造林実施状況

\begin{tabular}{|c|c|c|c|c|c|}
\hline プロジェクト & $\begin{array}{l}\text { 事 業 } \\
\text { 着手年 }\end{array}$ & $\begin{array}{l}\text { 目標面積 } \\
\text { (千 ha) }\end{array}$ & $\begin{array}{c}1992 \text { 年末 } \\
\text { までの } \\
\text { 造林面積 } \\
(千 \mathrm{ha})\end{array}$ & 主要 樹 種 & 考 \\
\hline （社）南方造林協会（9社） & 1970 & 試験造林 & 1.4 & 各種 & 通産省補助 \\
\hline 日伯紙パルプ資源開発 (17社) & 1973 & 110 & 88.4 & ユーカリ & $\begin{array}{l}\text { OECF出資のナショ } \\
\text { プロジェクト }\end{array}$ \\
\hline 本州製紙パプアニューギニア & 1975 & 10 & 6.5 & ユーカリ, アカシア & 当初は JICA 試験事業 \\
\hline 三菱製紙ニューカレドニア & 1975 & 試験造林 & 0.2 & ユーカリ & JICA 試験事業 \\
\hline タイユーカリ資源 (14 社) & 1988 & $(200)$ & - & ユーカリ & 契約栽培 \\
\hline 大王製紙チリ第 $\mathrm{X}$ 区 & 1989 & 65 & 6.0 & ユーカリ, マツ & \\
\hline 三药製紙 チ少第 VIII 区 & 1990 & 10 & 3.4 & ユーカリ & \\
\hline 日本製紙千少第细区 & 1991 & 14 & 1.1 & ユーカリ & \\
\hline $\begin{array}{l}\text { 新王子製紙・日本製紙ニュー } \\
\text { ジーランド北島 }\end{array}$ & 1991 & (30) & - & マツ & $\begin{array}{l}\text { 国有ラジアータマッ年権取得で伐採, } \\
\text { 林の利告告林を実施 }\end{array}$ \\
\hline 新王子製林ニュージーランド南島 & 1992 & 10 & 0.5 & ユーカリ & \\
\hline 新王子製紙西オーストラリア & 1993 & 20 & - & ユーカリ & \\
\hline 新王子製紙造林試験( 3 力国) & $1991 \sim$ & - & 0.1 & ユーカリ, アカシア & $\begin{array}{l}\text { パプアニューギニア, ヘ } \\
\text { トナム, フィジー }\end{array}$ \\
\hline 計 & & 469 & 107.6 & & \\
\hline
\end{tabular}

注：1。目標面積の合計には（）を含む。

2.（社）南方造林協会および三菱製紙ニューカレドニアの試験造林は終了。

(マツ属)，カメレレなどの Eucalyptus（ユーカリ属） のほか, Albizia(ネムノキ属), Terminalia(ターミナ リア属), Gmelina (メリーナまたはメライナ属) など で, 合計 20 種近くに及んでいる。

その後は直接の造林事業は実施していないか，通算 90 回近い調查団や技術者の派遗を実施してきており， 造林やチップ輸入の新規プロジェクトの発掘はもとよ ク, 人材の有成や, 我か国の海外開発協力事業(ODA) などに貢献してきている。

（2）日伯紙パルプ資源開発プロジェクト

フラジルの国策資源会社リオ・トーーセ社が供給する 既存のユーカリ造林木を原料にパルプを生産し，その 半分を対日輸出する目的で，リオ・ドーセ社と日伯紙 パルプ资源開発修の合弁によるセニブラ社が 1973 年 にまたこれとは別にユーカリの造林を実施し，チッ プないしはパルプの生産, 輸出を行う構想の合弁会社 フロニブラ社が 1974 年にそれぞれ設立された。

しかし,これらはオイルショックの影響を受け, 1984 年に両社は合併して新生のたニブラ社となり, 造林か
らパルプ生産までを一貫して行うこととなった。

現在,この社が睡入済みの社有地は 155 千 ha で, こ のうち 1992 年末までに 88 千 ha が造林されている。 樹種は E. grandis の単植が $79 \%$, 同種と E. saligna と の混植が $9 \%$, E. saligna の単植が $6 \%$, その他のユー カリが $6 \%$ の割合となっている。伐採は 8 年目 (7 年生) で行い，チップ用丸太の収穫量（皮なし）は，ha 当た り平均で $160 \mathrm{~m}^{3}$ となっている。

なお，現在の出凟割合はリオ・ドーセ社が $51.5 \%$ ， 日伯紙パルプ资源開発俶が $48.5 \%$ で，日産 $1,000 \mathrm{tの}$ BKP を生産し，その $50 \%$ を我が国の参加製紙各社に 供給している。

（3）本州製紙のパプアニューギニアプロジェクト 熱帯天然林はほとんどが広葉樹で，極めて多数の樹 種の混交林となっているのが普通であり，材色も淡白 色から紫黒色まで，また，比重もバルサのように警く ほど軽いものから沈木 (sinker) まで実に様々である。 熱帯天然林のミックス材（このうち筏で沖䅪みの可能 なものか，当初，我が国の木材関係商社筋で Tropical 
Mixed Light Hardwood：通称，MLH といわれてき たが, 現在では sinkerも含めて, MLH といわれてい る）が，我が国の製紙業界でほとんど利用されていな い理由でもある。

本州製紙のプロジェクトは，すでに述へたように山 火事再生林 (約 50 年生) が対象で, 総合開発計画のた めにこれらの材の利用を要請され，板紙用に使用して きたものである。しかし伐採跡地の開発利用が進まな かったため, 1975 年から, JICA 融資の試験造林事業を 行ってきたが, 1977 年に至り，本州製紙側の企業 JANT 社が $51 \%$, パプアニューギニア政府が $49 \%$ 出 資のゴゴール・リフォレステーション社が設立され， 本格的に造林を実施することとなったものである。

1992 年末までに, 郷土種である E. deglupta (カメレ レ)を主に 6,500 ha の造林を行ってきたが，すでに述 べたように幼跲時から材の心腐れの発生があるなどの 理由で、将来的には Acacia mangium を $80 \%$ 程度と し， 10,000 ha に拡大する計画である。

なお、この Acacia mangiumはマメ科の植物で, 空 中室素を固定する根粒を持っている。パプアニューキ ニア, インドネシア (モルッカ諸島, イリアンジャヤ) やオーストラリア北部など，熱帯多雨地域が原産で成 長が早く，マレーシアなどで大規模に造林されてきた が, 10 年生前後から材の心鹰れか発生し, 材質的にも 一般用材としては市場性がそしいことなどから，最近 ではマレーシア政府は造林を見合わせている。ただし， 10 年生前後で利用するパルプ用では, パルプ適性の面 からも格別の問題はないと見られている。なお，筆者 の経験では, 年降雨量が $1,000 \mathrm{~mm}$ を下回る夕イの中 央部一東北部のような地域での本種の成育はかなり 劣っており, 留意する必要があるように思われる。

（4）タイ・ユーカリ資源プロジェクト

タイでは戦後の 1947 年から 1988 年の 41 年間に, 人 口が 3.2 倍, 農用地面稹が 2.2 倍となり, 森林面積が 約半減 $(1,293$ 万 ha 減) するという事態を招いてい る。

このような事情のもとで，㚼作の中心であった キャッサバ (夕ピオカ) が国際的に不振となってきた ため, 1984 年頃からユーカリ（ほとんどE. camal. dulensis) への転作が進められるようになってきた。

このため，タイ政府は日本製紙連合会などに対し， ユーカリ材のマーケットの提供や造林技術指導などに ついて要請を行うようになり，1988年に日本製紙連合 会理事会の梖同を得て，15 社の参加 (現在 14 社)によ り取り組むこととなったのが本プロシェクトである。

用地問題もあり，タイ政府の管挐する契約栽培方式
によることとしたのだが，その後の度重なる政変や， 後述するように, 政府実施の国有林復旧造林で, 違法 侵入農民の排除をめぐるトラブルに端を発したユーカ リ造林反対運動などから本格実施に至っていない。

一方，農民や一部地元企業などがすでに植栽してき たユーカリのマーケットの問題があり，1992 年から は, 当面, 伊藤忠商事が設立する現地合弁会社が, こ れらのユーカリを買い取って生産するチップの全量を 引き受けることとし現在に至っている。

国土の早期緑化要請と，ますます悪化しつつある キャッサバの国際市場問題や，ユーカリ造林が環境に 悪影響を及ほすとされてきた諸批判に対する科学的反 証などが進むにつれて，ユーカリ造林に对する世論も 好転しつつあり, 政府も造林推進のための諸制度の整 備などに積極的な取り組みを始めている。今しばらく， これらの動向を見守る必要がある。

(5）チリのプロジェクト

(i) 大王彆紙のプロジェクト

1989 年に大王製紙 $90 \%$ ，伊藤忠商事 $10 \%$ の出資割 合でフォレスタル・アンチレ社を設立。第X地区に 65 千 ha の用地を取得し, E. globulus を2/3, 残りは $P$. radiata (ラジアータマツ) を造林し, 平均伐採羭 10 年 で年間約 100 万 $\mathrm{m}^{3}$ の収穫を見込んでいる。すでに 1992 年末でユーカリ 5,300 ha, ラジアータマッ 700 ha を造林している。現地でパルプ (BKP) を生産する計 画である。

(ii） 三菱製紙のプロジェクト

1990 年に三菱製紙 $50 \%$ 、三菱商事 $50 \%$ の出資割合

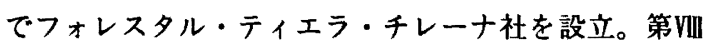
地区に 13 千 haの用地を取得し，E. globulus を 10 干 ha 造林する計画で, すでに 1992 年末で 3,415 ha を造 林している。伐採䑪 12 年で年間約 30 万 $\mathrm{m}^{3}$ のチップ の生産, 輸出を見込んでいる。

（iii） 日本製紙のプロジェクト

1991 年に元山陽国策パルプ, 住友商事と現地のイン バーショネス・マガジャネス社の均等出資でウォルテ ラ社を設立。第训地区に 14 千 ha の用地を取得して $E$. globulus を造林する計画で，すでに 1992 年末で 5 干 ha の用地を得, 1,100 ha を造林している。伐採粭 10 年 で年間約 36 万 $\mathrm{m}^{3}$ のチップの生産, 輸出を見込んでい る。

（6）新王子製紙・日本製紙のニュージーランド北 島プロジェクト

同国の北島にはすでに 1971 年に元王子製紙, 元山陽 国策パルプと現地の森林企業カーター・ホルト・ハー ベイ・リミティド (CHHL) の合弁によって設立され 
たカーター・王子・国策・パンパシフィック社 (1993 年に元王子製紙と新たに設立された日本製紙がカー ター社の持ち株を買い取ったため, 社名をパンパシ フィック・フォレストインダストリーズ社に変更）が あり,すでにパルプの生産, 輸出を行ってきている。

同国では 1987 年から国営事業民営化政策がとられ てきたため，元王子製紙と元山陽国策パルプは，1991 年にラジアータマッの人工林を主とする国有林約 3 万 haの 70 年間にわたる利用権を取得し, 伐採と並行し て造林を進め, 同国から輸入する製紙原料をこの山林 経営によって賄うこととしたものである。

（7）新王子製紙のニュージーランド南島プロジェ クト

1992 年に伊藤忠商事とともに植林事業会社（略称 SPFL 社) を設立。E. nitens を 1992 年に 520 ha 造林 し, 1993 年以降, 年約 800 ha の造林を実施する計画で ある。最終的には約 10 千 ha とし, 年間 20 万 $\mathrm{m}^{3}$ の チップの生産, 輸出を見込んでいる。

（8）新王子製紙の西オーストラリアプロジェクト 1991 年に Albany 地区に試験地を設定して調查・検 討を行い, 1993 年に伊藤忠商事とともに植林事業会社 (略称 APFL 社)を設立。E. globulus を 1993 94 年は 各 $1,000 \mathrm{ha}$, 以降は年約 2,000 ha の造林を実施する計 画である。最終的には約 20 千 ha とし, 年間 40 万 $\mathrm{m}^{3}$ のチップの生産, 輸出を見込んでいる。

（9）新王子製紙の光の他のプロジェクト

新王子製秖は以上のほか, 同社の林木育種場の指導 のもとに, 日商岩井と共同で, 1991 年からパプア ニューギニアで, 1992 年からべトナムで各約 50 ha の 試験造林に着手するとともに, 1993 年からはフィジー で, 伊藤忠商事と現地の FPL 社 (Fiji Pine Ltd.) と の共同による約 30 ha の試験造林に着手している。そ れぞれ, 造林樹種, 造林方法などについて約 3 年間の 調查・検討を行い，本格事業に移行する計画である。

試験樹種の主なものは, ユーカリではE. camal. dulensis, E. tereticornis, アカシアでは A. mangium, A. auriculiformis となっている。

\section{1. ユーカリ ジレンマ}

ユーカリ造林が界各地で搪大するにつれて, 種々 の批判や，地域によっては造林反対運動などが見られ るようになっている。その主なものとしては，(1)先に 述べたタイでの例のように，人口の增大にともなう焼 㚼の拡大などで失われた森林の復旧をめぐり，移動を 余儀なくされる農民の支援のためのユ一カリ造林批判 や，展民によるユーカリ造林実力阻止行動, 時にはユー
カリ造林地の焼払い事件などがあり，また，(2)インド での例のように，農業経営の改善策として政府が奖励 してきた農家林業 (agroforestry) で造林されたユーカ リが，地域によってはその市場が遠かったり，各造林 地が小規模分散的であるなどのほか，早期収入を得る ために若秢で伐採されるものが多いなどで需給のアン バランスを招き，期待した価格での販売ができなかっ たことや，一方，農地の畔などに植えられたもので， 農産物の収穫に悪影響を与えたものがあるなどから， 農民の不信や反発を招いているものがある。

以上の上うな社会・経済的事情に起因するもののほ か, ユーカリそのものが, (3)外来種で, 成長が早く, 根を深く広く張るために土壤の水分や笭分を吸収し過 ぎこと，また，(4)そのために地表植生の成育が抑制 され，降雨による土壤浸食が生しやすいこと，(5)野生 動物に对する䬺や生息場所の提供に問題があることな ど，その特異な生理・生態性を有害とする批判も行わ れている。

ただ,このようにユーカリそのものを有害とする論 も，しばしば上記の社会・経斉的事情によるユーカリ 造林反对運動の拠り所とされ, 問題を一層複雑・困難 なものとしている例が多い。

このため，以前からユーカリ造林の推進に努めてき たFAOでは，1988年に「The Eucalypt Dilemma」 と題した報告書を公にしている。

この報告書では, 初めにユーカリ造林に対する賛成 論と反对論の要旨を揭げ，それぞれについて草地，か ん木地, 農地や他樹種の林などとの比較測定デー夕な どをもととしながら検討を行っている。

これらを全体的に見れば，ユーカリが環境などに及 ほす影響には，立地条件や森林の扱い方（伐採龄や落 葉・落枝の採取の有無など）によって差があり，他の 樹種にくらへて、ユーカリだけが特に有害とか有益と いった結論は得られていない。このことから、ユーカ リ造林に対する評価は「土地の潜在的生産能力と, 地 域のニーズに最も合った土地利用」という観点で判断 されるべきものであると結んでいる。

タイ政府農業・協同組合省では, $8 \sim 10$ 年間, 無施肥 でキャッサバを栽培した場合とユーカリを造林した場 合の比較試験結果として, (1)土壤肥沃度, 土壤崩壤率, 土壤構造の変化などでは，ユーカリ植林の方が不良化 率が低い，(2)農作に不適な荒廃地にユーカリを植林す れば気温，湿度および生物の生存にとってよい条件を もたらすなどとした報告書を 1992 年 9 月に閣議に提 出し, 了承を得ている。

我か国の国際協力事業団 (JICA) でも，同団が実施 
する林業関係協力事業でユーカリを用いることが多い ため, 種々の批判を受けている。このため, ユーカリ の生理的・生態的特性についての各種研究報告を整理 し, 大学, 試験研究機関などの研究者から成る委員会 での審議を経て，1993 年 3 月に「ユーカリ類を用いた 林業協力事業に対する見解」を取りまとめている。

これによれば,「一概にユーカリはよいとか, 有害で あると断定できる共通的な答えは，これまでのところ ない」との結論に達している。

なお, 造林の基本は「適地適木」であり，「結果的に ユーカリとなることが多く, 特に荒廃地では, 今のと ころユーカリが最も適した樹種と言わさるを得ない」 としている。ただ，当然のことではあるが，ユーカリ 類と同等以上の特性を持つ樹種の開発と, Z一カリ林 造成後, より有用な森林へ移行する技術の開発の必要 性も述へている。

ともあれ，利用度の低い草地，かん木地や低質林を そのまま放置しておくことよりも，どのような樹種で あれ造林することに利があるのは論を要しないところ であり，それはまた，残された天然林への利用圧力を 軽減することにもなるのである。ただし，単一樹種に よる大面積の画一的な造林については，今までよく言 われてきた病虫害の異常発生など, 重大障害例はまだ ほとんど見られないものの, 全般的な㻴境保全の観点 からも，十分に留意する必要があうう。

12. おわりに

1992 年のユーカリパルプ材の輸入量は 497 万 $\mathrm{m}^{3} て ゙$,
広葉樹パルプ材輸入量の $38 \%$, 国産も合わせた全広葉 樹パルプ材入荷量の $24 \%$ を占めるまでになっている。

また，ユーカリパルプ材輸入量のうち，人工林材率 は年々上昇して，1992 年には $36 \%\left(181\right.$ 万 $\left.\mathrm{m}^{3}\right)$ に達し ている。しかし，このうち我が国の製紙業界が自ら造 林したものは，まだ 5 万 $\mathrm{m}^{3}$ (本州製紙のプロジェクト 分だけで、ブラジルはパル化輸入) の段階にある。

パルプ材輸出国の, 自国内での高付加価值化志向は 強まりつつあり，たとえば, チリからのラジアータマ ツとユーカリの人工林材チップの輸入は, 1988 年頃か ら本格化したが，1992 年からは現地企業（米国企業な どとの合弁が多い) によるパルプ工場の新設で大きく 後退している。

この傾向は開発途上地域に限らず，先進諸国でもほ ほ同様であって, 環境保全問題による天然資源の利用 制約が、これを加速させてもいるようである。資源小 国である我か国の製紙産業か，英国製紙産業のてつを 踏まないためにも，利用の自由度，安定度の高い製紙 原料の確保策が，ますます重要な課題となってきてい る。

本稿では，ユーカリ材のパルプ適性などについては 全く触れていない。別途寄稿の予定があると聞いてい る。また, ユ一カリ造林の技術的問題, コストや今後 の課題などについても，紙面の関係でほとんど触れて いない。記述したものにも誤認・誤記や筆足らずの点 があるものと思われる。ご叱声をいただきたい。 